\title{
Article \\ Optimising Artificial Moss Growth for Environmental Studies in the Mediterranean Area
}

\author{
Zulema Varela ${ }^{1,2, *}$, Carlos Real ${ }^{3}$, Cristina Branquinho ${ }^{2}\left(\mathbb{D}\right.$, Teresa Afonso do Paço ${ }^{4}$ (D) \\ and Ricardo Cruz de Carvalho 2,5 (iD
}

1 CRETUS, Ecology Unit, Department Functional Biology, Facultade de Bioloxía, Universidade de Santiago de Compostela, 15782 Santiago de Compostela, Spain

2 Centre for Ecology, Evolution and Environmental Changes (cE3c), Faculdade de Ciências, University of Lisbon, 1749-016 Lisbon, Portugal; cmbranquinho@fc.ul.pt (C.B.); rfcruz@fc.ul.pt (R.C.d.C.)

3 Ecology Unit, Department Functional Biology, Escola Politécnica Superior de Enxeñaría (EPSE), Universidade de Santiago de Compostela, Rúa Benigno Ledo, Campus Terra, 27002 Lugo, Spain; carlos.real@usc.es

4 LEAF—Linking Landscape, Environment, Agriculture and Food—Research Center, Associated Laboratory TERRA, Instituto Superior de Agronomia, Universidade de Lisboa, Tapada da Ajuda, 1349-017 Lisboa, Portugal; tapaco@isa.ulisboa.pt

5 Marine and Environmental Sciences Centre (MARE), Faculdade de Ciências, Universidade de Lisboa, Campo Grande, Edifício C2, Piso 5, 1749-016 Lisboa, Portugal

* Correspondence: zulema.varela@usc.es; Tel.: +34-8818813314

check for

updates

Citation: Varela, Z.; Real, C.; Branquinho, C.; do Paço, T.A.; Cruz de Carvalho, R. Optimising Artificial Moss Growth for Environmental Studies in the Mediterranean Area. Plants 2021, 10, 2523. https:// doi.org/10.3390/plants10112523

\section{Academic Editors:}

Daniel Sánchez-Mata and Andrew J Wood

Received: 29 September 2021

Accepted: 17 November 2021

Published: 19 November 2021

Publisher's Note: MDPI stays neutral with regard to jurisdictional claims in published maps and institutional affiliations.

Copyright: (c) 2021 by the authors. Licensee MDPI, Basel, Switzerland. This article is an open access article distributed under the terms and conditions of the Creative Commons Attribution (CC BY) license (https:/ / creativecommons.org/licenses/by/ $4.0 /)$.

\begin{abstract}
Bryophytes are poikilohydric organisms that play a key role in ecosystems, while some of them are also resistant to drought and environmental disturbances but present a slow growth rate. Moss culture in the laboratory can be a very useful tool for ecological restoration or the development of urban green spaces (roof and wall) in the Mediterranean region. Therefore, we aim to: (i) determine the optimal culture conditions for the growth of four moss species present in the Mediterranean climate, such as Bryum argenteum, Hypnum cupressiforme, Tortella nitida, and Tortella squarrosa; (ii) study the optimal growth conditions of the invasive moss Campylopus introflexus to find out if it can be a threat to native species. Photoperiod does not seem to cause any recognisable pattern in moss growth. However, temperature produces more linear but slower growth at $15^{\circ} \mathrm{C}$ than at 20 and $25^{\circ} \mathrm{C}$. In addition, the lower temperature produced faster maximum cover values within 5-8 weeks, with at least $60 \%$ of the culture area covered. The study concludes that the culture of moss artificially in the organic gardening substrate without fertilisers is feasible and could be of great help for further use in environmental projects to restore degraded ecosystems or to facilitate urban green spaces in the Mediterranean area. Moreover, this study concludes that $C$. introflexus could successfully occupy the niche of other native moss species, especially in degraded areas, in a future global change scenario.
\end{abstract}

Keywords: bryophytes; ecological restoration; green roofs; Moss cover; photoperiod; temperature

\section{Introduction}

Mosses play an important role in ecosystems. They help improve soil stability, fix basic nutrients like nitrogen $(\mathrm{N})$ and carbon $(\mathrm{C})$, and increase the organic matter content in soils, facilitating other plants to grow roots and serving as a habitat for other organisms [1]. They are also susceptible to rapid dehydration under low relative humidity and quickly resume metabolic activity upon rehydration [2-4]. Furthermore, mosses can recover quickly after an environmental perturbation, being one of the earlier colonizers among biological soil crust (BSC) components [5]. Moreover, they are totipotent, i.e., any vegetative moss tissue can be a propagule from which grows a new plant [6]. In addition, due to their poikilohydric nature, they have a great ability to capture and retain atmospheric pollutants and, therefore, are widely used to monitor air quality $[7,8]$.

All these characteristics make mosses the ideal organisms for ecological restoration projects in disturbed ecosystems $[9,10]$ or even for use on roofs and green walls in urban 
environments [11]. However, is to not acceptable to harvest mosses in the field and transplant them elsewhere, as their growth rate in the natural environment is very slow. For example, Giquan et al. [12] report that moss Bryum argenteum is able to cover $70 \%$ of $10 \times 10 \mathrm{~cm}$ squares in 3-4 years in desert dunes, so another source of mosses is needed, which is why laboratory cultures were started. Studies aimed at restoring or rehabilitating dryland areas have been artificially growing moss for years [10,12-21]. The procedure followed by most of these works is practically the same: they collect bryophytes of BSCs from the study area and grow them in greenhouses or growing chambers inside plastic containers using autoclaved sand from such areas as a substrate and adding culture medium to speed up their growth. However, these moss culture methods have been poorly described and no information is available concerning their performance. It is unknown which photoperiod or temperature they use to cultivate the different species or if the moss samples were irrigated for most studies. It is only noted that high rates of moss growth are reached in two and six months.

However, there is scarce previous experience of artificial moss culture in non-arid environments in Europe, unlike in North America or Asia for gardening and even moss graffiti [22,23]. Although there are many arid areas in the Mediterranean area, plenty of other areas have a temperate climate and, therefore, other types of ecosystems and other moss species adapted to these conditions. According to Proctor [24], the main growth period for most bryophytes in temperate climates with uniform rainfall throughout the year tends to be in autumn. In winter, growth is limited by low temperatures and in summer by lack of water [25,26]. Furnes and Grime [27] noted that the optimum temperature for the growth of most species is between 15 and $25^{\circ} \mathrm{C}$. Glime [28] conjectures that temperature may control when and where species germinate and thus limit their distribution. However, this author reported that each moss species will grow at a certain rate and that this will be determined by factors other than temperature, such as the photoperiod and its intensity, the species' morphology, and its growth or life form. For example, in the moss Ceratodon purpureus, long days stimulate protonema elongation, while short days result in protonema branching. Meanwhile, in Bryum pseudotriquetrum, days of ten or more hours are necessary for protonema germination and growth. Therefore, there is undoubtedly a need to optimise the specific technique for the species of interest for cultivation.

This study aims to: (i) determine the optimal culture conditions for the following four moss species commonly found in the Mediterranean (dry summer) climate zones as a tool to facilitate ecological restoration or green roofs/walls projects: Bryum argenteum, Hypnum cupressiforme, Tortella nitida, and Tortella squarrosa. On one hand, B. argenteum, T. nitida, and T. squarrosa are acrocarpic moss species very common in the Mediterranean and quite tolerant to desiccation [29]. An example of pleurocarpic moss is H. cupressiforme, a cosmopolitan species which is present in every continent (except Antarctica) and spread over a wide range of habitats and climatic areas [29]. Our second aim is to (ii) study the optimal growth conditions of the invasive moss Campylopus introflexus to find out if it can be a threat to native species. This species is considered one of the 100 worst alien species in Europe [30]. Moreover, this moss is native to the southern hemisphere and was introduced to Europe in the 1940s [31], and its spread has been increasing with climate change.

\section{Results}

Table 1 shows the average of the initial, final, and maximum cover, and the time it took to reach this maximum cover. The variability within all treatment combinations was large (standard deviation up to 29\%), even though the initial conditions were the same for all replicates. At $15^{\circ} \mathrm{C}$, the maximum cover was reached towards the end of the experiment (eight weeks) in most cases, while at 20 and $25^{\circ} \mathrm{C}$ the maximum cover was usually reached between weeks 4 and 6, decreasing afterwards. It should also be noted that, except for C. introflexus, species reached the maximum cover at $15^{\circ} \mathrm{C}$, decreasing slightly at $20^{\circ} \mathrm{C}$ and more at $25^{\circ} \mathrm{C}$. 
Table 1. Mean of the initial, final, and maximum coverage (\%) and the standard deviation of the different moss species for the different variables and time (weeks) to cover it.

\begin{tabular}{|c|c|c|c|c|c|c|}
\hline Species & $\mathrm{T}\left({ }^{\circ} \mathrm{C}\right)$ & $\begin{array}{l}\text { Photoperiod } \\
\text { (Hours) }\end{array}$ & $\begin{array}{c}\text { Initial Cover } \\
(\%)\end{array}$ & $\begin{array}{c}\text { Final Cover } \\
(\%)\end{array}$ & $\begin{array}{c}\text { Max. Cover } \\
(\%)\end{array}$ & $\begin{array}{c}\text { Time to Max. } \\
\text { Cover } \\
\text { (Weeks) }\end{array}$ \\
\hline \multirow{9}{*}{$\begin{array}{c}\text { Bryum } \\
\text { argenteum }\end{array}$} & \multirow{3}{*}{15} & $12 \mathrm{~h}$ & $8.63 \pm 2.15$ & $58.10 \pm 10.95$ & $58.10 \pm 10.95$ & 8 \\
\hline & & $16 \mathrm{~h}$ & $23.60 \pm 7.81$ & $69.01 \pm 11.40$ & $69.01 \pm 11.40$ & 8 \\
\hline & & $20 \mathrm{~h}$ & $25.77 \pm 5.89$ & $64.54 \pm 13.31$ & $64.54 \pm 13.31$ & 8 \\
\hline & \multirow{3}{*}{20} & $12 \mathrm{~h}$ & $21.87 \pm 6.73$ & $22.78 \pm 6.03$ & $54.82 \pm 12.73$ & 5 \\
\hline & & $16 \mathrm{~h}$ & $16.53 \pm 9.05$ & $35.43 \pm 3.81$ & $50.26 \pm 18.74$ & 5 \\
\hline & & $20 \mathrm{~h}$ & $10.37 \pm 4.67$ & $46.38 \pm 9.86$ & $60.87 \pm 21.07$ & 6 \\
\hline & \multirow{3}{*}{25} & $12 \mathrm{~h}$ & $22.27 \pm 8.45$ & $39.13 \pm 10.88$ & $55.96 \pm 12.69$ & 6 \\
\hline & & $16 \mathrm{~h}$ & $31.63 \pm 4.33$ & $39.95 \pm 6.88$ & $49.93 \pm 7.13$ & 4 \\
\hline & & $20 \mathrm{~h}$ & $26.93 \pm 0.44$ & $40.92 \pm 4.24$ & $46.17 \pm 10.87$ & 4 \\
\hline \multirow{9}{*}{$\begin{array}{c}\text { Campylopus } \\
\text { introflexus }\end{array}$} & \multirow{3}{*}{15} & $12 \mathrm{~h}$ & $17.09 \pm 2.49$ & $56.43 \pm 31.62$ & $56.43 \pm 31.62$ & 8 \\
\hline & & $16 \mathrm{~h}$ & $21.24 \pm 2.99$ & $73.98 \pm 3.32$ & $73.98 \pm 3.32$ & 8 \\
\hline & & $20 \mathrm{~h}$ & $27.56 \pm 2.26$ & $62.23 \pm 13.90$ & $62.23 \pm 13.90$ & 8 \\
\hline & \multirow{3}{*}{20} & $12 \mathrm{~h}$ & $22.04 \pm 5.45$ & $41.89 \pm 24.65$ & $74.12 \pm 8.47$ & 6 \\
\hline & & $16 \mathrm{~h}$ & $19.68 \pm 4.18$ & $44.15 \pm 35.21$ & $69.33 \pm 7.62$ & 6 \\
\hline & & $20 \mathrm{~h}$ & $22.40 \pm 8.70$ & $41.40 \pm 12.56$ & $52.28 \pm 2.28$ & 7 \\
\hline & \multirow{3}{*}{25} & $12 \mathrm{~h}$ & $18.61 \pm 7.53$ & $49.81 \pm 11.68$ & $55.47 \pm 19.45$ & 5 \\
\hline & & $16 \mathrm{~h}$ & $24.24 \pm 5.90$ & $56.80 \pm 18.46$ & $64.48 \pm 17.68$ & 7 \\
\hline & & $20 \mathrm{~h}$ & $21.16 \pm 1.08$ & $72.00 \pm 3.20$ & $72.47 \pm 0.44$ & 7 \\
\hline \multirow{6}{*}{$\begin{array}{c}\text { Hypnum } \\
\text { cupressiforme }\end{array}$} & \multirow{3}{*}{15} & $12 \mathrm{~h}$ & $11.35 \pm 2.12$ & $49.24 \pm 11.87$ & $49.24 \pm 11.87$ & 8 \\
\hline & & $16 \mathrm{~h}$ & $24.53 \pm 8.11$ & $60.46 \pm 8.79$ & $60.46 \pm 8.79$ & 8 \\
\hline & & $20 \mathrm{~h}$ & $23.71 \pm 7.33$ & $52.40 \pm 33.10$ & $53.33 \pm 9.22$ & 4 \\
\hline & \multirow{3}{*}{20} & $12 \mathrm{~h}$ & $12.03 \pm 4.45$ & $22.44 \pm 5.79$ & $41.5 \pm 23.66$ & 5 \\
\hline & & $16 \mathrm{~h}$ & $6.86 \pm 1.23$ & $47.92 \pm 12.27$ & $32.93 \pm 17.73$ & 5 \\
\hline & & $20 \mathrm{~h}$ & $4.49 \pm 2.06$ & $34.51 \pm 20.34$ & $64.08 \pm 25.55$ & 4 \\
\hline \multirow{9}{*}{ Tortella nitida } & \multirow{3}{*}{15} & $12 \mathrm{~h}$ & $4.88 \pm 0.75$ & $77.89 \pm 5.61$ & $77.89 \pm 5.61$ & 8 \\
\hline & & $16 \mathrm{~h}$ & $5.32 \pm 1.99$ & $74.30 \pm 11.67$ & $70.87 \pm 17.74$ & 6 \\
\hline & & $20 \mathrm{~h}$ & $3.92 \pm 0.35$ & $61.46 \pm 24.99$ & $68.53 \pm 13.23$ & 5 \\
\hline & \multirow{3}{*}{20} & $12 \mathrm{~h}$ & $2.71 \pm 0.65$ & $46.38 \pm 20.83$ & $54.85 \pm 6.26$ & 6 \\
\hline & & $16 \mathrm{~h}$ & $2.69 \pm 2.14$ & $18.05 \pm 8.58$ & $61.40 \pm 12.93$ & 5 \\
\hline & & $20 \mathrm{~h}$ & $2.56 \pm 0.85$ & $50.78 \pm 12.54$ & $73.26 \pm 2.65$ & 5 \\
\hline & \multirow{3}{*}{25} & $12 \mathrm{~h}$ & $3.10 \pm 1.90$ & $47.40 \pm 18.06$ & $56.54 \pm 7.57$ & 5 \\
\hline & & $16 \mathrm{~h}$ & $2.00 \pm 0.71$ & $32.10 \pm 19.31$ & $33.36 \pm 16.23$ & 5 \\
\hline & & $20 \mathrm{~h}$ & $3.16 \pm 0.47$ & $43.02 \pm 29.56$ & $43.02 \pm 29.56$ & 8 \\
\hline \multirow{9}{*}{ Tortella squarrosa } & \multirow{4}{*}{15} & $12 \mathrm{~h}$ & $15.68 \pm 3.43$ & $40.30 \pm 27.24$ & $43.52 \pm 18.14$ & 6 \\
\hline & & $16 \mathrm{~h}$ & $15.88 \pm 2.36$ & $67.09 \pm 16.27$ & $67.09 \pm 16.27$ & 8 \\
\hline & & $20 \mathrm{~h}$ & $14.99 \pm 4.90$ & $69.15 \pm 5.06$ & $69.15 \pm 5.06$ & 8 \\
\hline & & $12 \mathrm{~h}$ & $17.21 \pm 6.19$ & $34.65 \pm 20.59$ & $64.21 \pm 25.26$ & 5 \\
\hline & \multirow[t]{2}{*}{20} & $16 \mathrm{~h}$ & $18.03 \pm 10.46$ & $35.67 \pm 17.83$ & $49.63 \pm 26.86$ & 5 \\
\hline & & $20 \mathrm{~h}$ & $19.29 \pm 5.13$ & $36.49 \pm 10.86$ & $47.48 \pm 28.05$ & 5 \\
\hline & \multirow{3}{*}{25} & $12 \mathrm{~h}$ & $20.87 \pm 2.53$ & $43.20 \pm 2.82$ & $43.20 \pm 2.82$ & 8 \\
\hline & & $16 \mathrm{~h}$ & $15.54 \pm 3.65$ & $52.76 \pm 3.00$ & $52.76 \pm 3.00$ & 8 \\
\hline & & $20 \mathrm{~h}$ & $20.14 \pm 6.30$ & $44.64 \pm 6.66$ & $48.15 \pm 3.56$ & 5 \\
\hline
\end{tabular}

The adjusted GAM curves (Figure 1) showed a linear growth pattern at $15{ }^{\circ} \mathrm{C}$ and parabolic growth patterns at $20^{\circ} \mathrm{C}$ and $25^{\circ} \mathrm{C}$, in line with the results of the maximum coverage. The determination coefficients $\left(\mathrm{r}^{2}\right)$ for all curves were significant $(p<0.05)$, with the higher values being mostly at $15^{\circ} \mathrm{C}$ (e.g., T. nitida with a photoperiod of $12 \mathrm{~h}, \mathrm{r}^{2}=0.96$ ), except for $H$. cupressiforme which is at $20^{\circ} \mathrm{C}$, with a photoperiod of $20 / 4 \mathrm{~h}\left(\mathrm{r}^{2}=0.45\right)$ and with slightly lower adjusting values. 

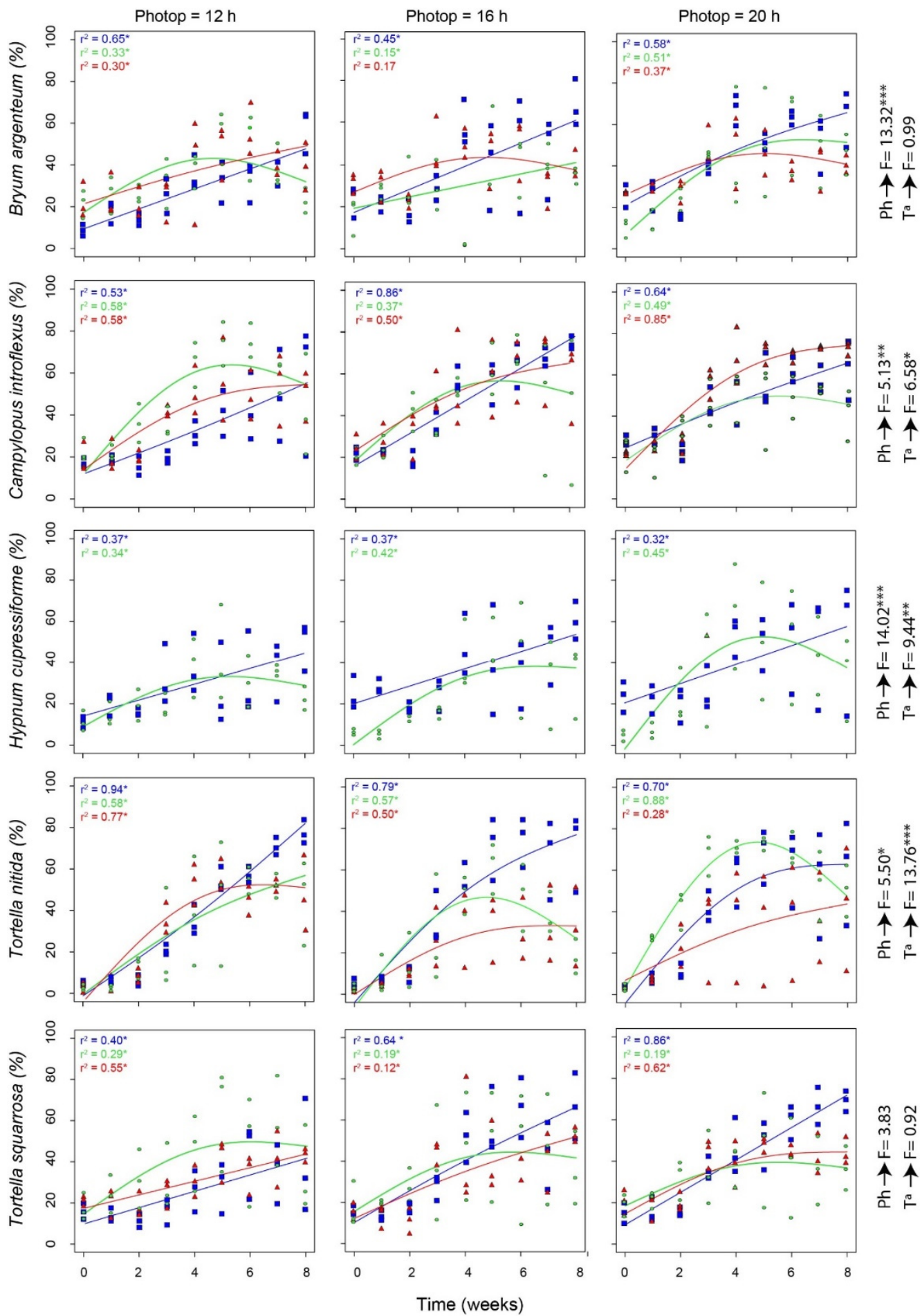

Figure 1. Tendency of a generalized additive model (GAM) for the coverage of the different moss species and the photoperiods and the different temperatures (Solid lines: blue $=15^{\circ} \mathrm{C}$, green $=20^{\circ} \mathrm{C}$ and red $\left.=25^{\circ} \mathrm{C}\right)$, adjusted $\mathrm{r}^{2}$, F-value $(\mathrm{F})$ for both variables and $p$-value $\left({ }^{* *} p<0.001 ;{ }^{* *} p<0.01\right.$; * $p<0.05)$.

On the other hand, a significant response of moss growth to the studied variables was not always found (see F-value in Figure 1). Thus, while C. introflexus, H. cupressiforme, and T. nitida showed a significant response to temperature and photoperiod, B. argenteum showed it to photoperiod only and T. squarrosa is independent of both. 


\section{Discussion}

\subsection{Moss Species Growth}

The culture of different moss species in growth chambers was very satisfactory. Growth was observed for all species and all treatments, in some cases covering almost $80 \%$ of the culture area. High variability was also found, which could be caused by working with fragments of live mosses as some can grow larger than others. Nevertheless, this variability, which is impossible to predict, would not limit the moss growth technique for use in environmental studies.

According to the literature, the optimum growth for most moss species is between 15 and $25{ }^{\circ} \mathrm{C}$ [27]. In general, we observed a lower growth rate at $15^{\circ} \mathrm{C}$ with a linear pattern that reached maximum coverage towards the end of the experiment (Table 1 and Figure 1). In contrast, at 20 and $25{ }^{\circ} \mathrm{C}$, we observed that the maximum rate of growth for species is reached towards the middle of the experiment, as if they were reaching their optimal growth and from then they start to die and the cover decreases. Higher temperatures will favour higher photosynthesis and therefore a higher rate of growth [25], but due to some unidentified stress (maybe competition between different moss fragments) the mosses under these conditions start to die midway through the experiment. Regarding photoperiod, it could be expected that more hours of light would favour growth [28] and despite finding significant relations between photoperiod and the rate of growth of B. argenteum, C. introflexus, H. cupressiforme, and T. nitida (see Figure 1), the maximum cover was achieved in any of the three photoperiods without any apparent pattern. In vascular plants, the temperature is one of the key factors determining their metabolism, growth, and distribution, so it could be assumed that temperature is more limiting than photoperiod for moss growth [32].

It would be expected that acrocarpous species, such as B. argenteum, T. nitida, and T. squarrosa, would grow more at higher temperatures and with longer photoperiods. These smaller species with cushion life forms can equilibrate more slowly with the relative humidity of their environment and therefore resist desiccation better $[4,33]$. However, this was only observed for T. nitida where the growth achieved at $20^{\circ} \mathrm{C}$ and with a $20 / 4 \mathrm{~h}$ photoperiod was much higher than for other temperatures. Although these species are resistant to desiccation, with the increase in temperature there may have been a decrease in water availability and therefore a change in growing conditions that has affected them.

In contrast, the only pleurocarpous moss in the study, Hypnum cupressiforme, does not seem to reach the cover levels of the acrocarpous mosses and shows more growth at lower temperatures $\left(15^{\circ} \mathrm{C}\right)$, except at certain times of the $20 / 4 \mathrm{~h}$ photoperiod. H. cuppresiforme is cosmopolitan and its life form is mats, which are more commonly found in humid and shady sites [34]. Therefore, temperatures generally above $20^{\circ} \mathrm{C}$ could be limiting their growth, as observed in the pleurocarpous moss Hylocomium splendens whose photosynthetic activities and growth rates decreased in warming winters in subarctic areas [35].

As expected, for most species except $T$. squarrosa, temperature and photoperiod influenced their growth. In general, to achieve high coverage in a short time, growing the mosses at $20^{\circ} \mathrm{C}$ and with a $12 / 12 \mathrm{~h}$ photoperiod will allow to reach high cover in five weeks. If, on the other hand, the objective is to achieve maximum cover but at a slower rate, it is better to grow at $15^{\circ} \mathrm{C}$. Consequently, the next step would be to transplant this cultured moss to degraded ecosystems, arid areas, or urban green spaces in the Mediterranean area to confirm that the moss can grow in these conditions to aid restoration.

\subsection{Alien Invasive Species}

Campylopus introflexus is an invasive acrocarpic moss from the Southern Hemisphere that is widespread in Europe thanks to its high ecological tolerance [36] and ability to resist in environments with limited water availability [37]. There are no plans to use this exotic species in future restoration projects. However, our results showed that $C$. introflexus could interfere with the growth of other species when these are transplanted to the field [38]. The results show that it tends to grow more at higher temperatures, e.g., with a 12/12 h 
photoperiod it grows more at $20^{\circ} \mathrm{C}$ and $25^{\circ} \mathrm{C}$ than at $15{ }^{\circ} \mathrm{C}$ and with a $20 / 4 \mathrm{~h}$ photoperiod it grows more at $25^{\circ} \mathrm{C}$ (Figure 1). This means that in a possible future scenario of global change with increasing temperatures and increasing periods of drought, $C$. introflexus could successfully occupy the habitat of other native moss species, especially in degraded areas where it occurs frequently [28].

\section{Materials and Methods}

\subsection{Moss Processing and Experimental Design}

Moss species were collected from roadsides, full sun-exposed walls in dry sub-humid (Alegrete, Parque Natural de São Mamede; Barreiro, Setúbal, Portugal) to semiarid (Zebreira, Beira Baixa; Estremoz, Alto Alentejo, Portugal), from natural to urban locations (Table 2).

Table 2. Bryophyte species collected in the present study (clade, growth form, location, aridity index (1980-2010) (A.I.), natural $(\mathrm{N})$, or urban $(\mathrm{U})$ site, coordinates).

\begin{tabular}{|c|c|c|c|c|c|c|}
\hline Species & Plant Clade & Growth Form & Location & A.I. * & N/U & Coordinates \\
\hline $\begin{array}{c}\text { Bryum argenteum } \\
\text { Hedw. }\end{array}$ & $\begin{array}{l}\text { Bryophyta } \\
\text { (mosses) }\end{array}$ & Acrocarpous & Zebreira & Semi-arid & $\mathrm{U}$ & $\begin{array}{l}39^{\circ} 51^{\prime} 06.9^{\prime \prime} \mathrm{N} \\
7^{\circ} 04^{\prime} 22.9^{\prime \prime} \mathrm{W}\end{array}$ \\
\hline $\begin{array}{c}\text { Campylopus } \\
\text { introflexus (Hedw.) } \\
\text { Brid. }\end{array}$ & $\begin{array}{l}\text { Bryophyta } \\
\text { (mosses) }\end{array}$ & Acrocarpous & Barreiro & Dry sub-humid & $\mathrm{N}$ & $\begin{array}{l}38^{\circ} 36^{\prime} 50.5^{\prime \prime} \mathrm{N} \\
9^{\circ} 02^{\prime} 31.9^{\prime \prime} \mathrm{W}\end{array}$ \\
\hline $\begin{array}{c}\text { Hypnum } \\
\text { cupressiforme Hedw. }\end{array}$ & $\begin{array}{l}\text { Bryophyta } \\
\text { (mosses) }\end{array}$ & Pleurocarpous & $\begin{array}{c}\text { Alegrete (Parque } \\
\text { Natural de São } \\
\text { Mamede) }\end{array}$ & Dry sub-humid & $\mathrm{N}$ & $\begin{array}{l}39^{\circ} 15^{\prime} 14.6^{\prime \prime} \mathrm{N} \\
7^{\circ} 18^{\prime} 05.0^{\prime \prime} \mathrm{W}\end{array}$ \\
\hline $\begin{array}{l}\text { Tortella nitida } \\
\text { (Lindb.) Broth. }\end{array}$ & $\begin{array}{l}\text { Bryophyta } \\
\text { (mosses) }\end{array}$ & Acrocarpous & Estremoz & Semi-arid & $\mathrm{U}$ & $\begin{array}{l}38^{\circ} 48^{\prime} 01.8^{\prime \prime} \mathrm{N} \\
7^{\circ} 39^{\prime} 41.9^{\prime \prime} \mathrm{W}\end{array}$ \\
\hline $\begin{array}{l}\text { Tortella squarrosa } \\
\text { (Brid.) Lindb. }\end{array}$ & $\begin{array}{l}\text { Bryophyta } \\
\text { (mosses) }\end{array}$ & Acrocarpous & Zebreira & Semi-arid & $\mathrm{U}$ & $\begin{array}{l}39^{\circ} 51^{\prime} 06.9^{\prime \prime} \mathrm{N} \\
7^{\circ} 04^{\prime} 22.9^{\prime \prime} \mathrm{W}\end{array}$ \\
\hline
\end{tabular}

* Aridity Index (1980-2010) according to Kurz-Besson et al. (2016).

Samples were collected dry and stored in paper bags until use. Once in the laboratory, they were cleaned from plant remains, epiphytes, adhering soil particles, etc. and dried at room temperature (circa $20^{\circ} \mathrm{C}$ ). Once dried, the moss shoots were cut into smaller pieces with scissors to be used as propagules. The experiment was carried out in growth chambers (Aralab, Portugal). We filled $750 \mathrm{~mL}$ capacity plastic containers (length $=13.8 \mathrm{~cm}$, width: $11.8 \mathrm{~cm}$ and height: $5.0 \mathrm{~cm}$ ) with $150 \mathrm{~g}$ of the organic soil substrate commonly used for gardening (N: $150 \mathrm{mg} / \mathrm{kg}$; P: $150 \mathrm{mg} / \mathrm{kg}$; K: $205 \mathrm{mg} / \mathrm{kg}$; CaCO3: $6.34 \mathrm{mg} / \mathrm{kg}$; organic matter: $50 \% \pm 10 \%$; pH: $6 \pm 1$; Auchan) that we irrigated with $200 \mathrm{~mL}$ of water until all the substrate was humidified. Subsequently, we weighed different amounts of propagule according to the moss species and spread them by hand in the different containers considering 3 replicates per species and treatment. Once prepared, we maintained them under different controlled conditions of temperature $\left(15,20\right.$ and $\left.25^{\circ} \mathrm{C}\right)$ and photoperiod $(12 / 12 \mathrm{~h}$, $16 / 8 \mathrm{~h}$, and $20 / 4 \mathrm{~h}$, day/night). As each species has its optimum temperature and light, we decided to test between the minimum $\left(15^{\circ} \mathrm{C}\right.$ and $\left.12 \mathrm{~h}\right)$ and maximum range $\left(25^{\circ} \mathrm{C}\right.$ and $20 \mathrm{~h}$ ) that the literature reports for mosses' growth, to establish their temperature and light preferences [24]. The humidity remained constant at 50\% throughout the experiment and the samples were irrigated each week with $200 \mathrm{~mL}$ of tap water. The experiment was intended to last until the mosses attained a 100\% cover, but after 8 weeks there was an intense growth of fungi and algae in the samples, so the experiment was terminated. No fertilisers, antifungals, etc. were added during the time of the experiment. Photos of H. cupressiforme at $25^{\circ} \mathrm{C}$ were not included in the analysis as we were unable to differentiate the green moss pixels from the green algae that grew on these samples from the beginning of the experiment. 


\subsection{Moss Growth Measurement}

To estimate the growth of the mosses in a non-destructive way, we measured their cover weekly for the eight weeks of the experiment. To do this, we took digital RGB images (Nikon D5100 camera) of each container (1134 images $=4$ species $\times 3$ replicates $\times 3$ temperature treatments $\times 3$ light treatments $\times 9$ weeks $+H$. cupressiforme species $\times 3$ replicates $\times 2$ temperature treatments $\times 3$ light treatments $\times 9$ weeks). All images were taken in a well-lit area close to a window in the laboratory but avoiding direct sunlight, and with the camera set in automatic mode.

The colour differences between the substrate (dark brown/black) and the moss (various shades of green) allowed for the classification of the pixels of the images as substrate or moss, and the calculation of the percentage cover of the moss. To do this, the first step was to isolate the substrate area by colouring the other pixels in red (see Figure 2). We did this manually, using the masking routines in the Gimp Image Editor software (Berkeley, CA, USA). The second step was to classify the pixels. This was done using the functions in the R package pixelclasser [39], which allow the user to define classification rules using a set of test images containing examples of the categories to recognize. The import function of pixelclasser transforms the original RGB values into proportions (the so-called rgb colour space) which eliminates colour differences due to the intensity of illumination and simplifies the analysis of the image into a two-dimensional problem. The pixels are then plotted in the plane defined by two of the $\mathrm{r}, \mathrm{g}$, or $\mathrm{b}$ variables, and the user can trace one or more straight lines that serve as classifying rules for the pixels. This is a simplified, manual variant of the technique known as support vector machine [40,41]. Figure 2 illustrates the procedure in a series of three images.

$\mathbf{T}_{0}$

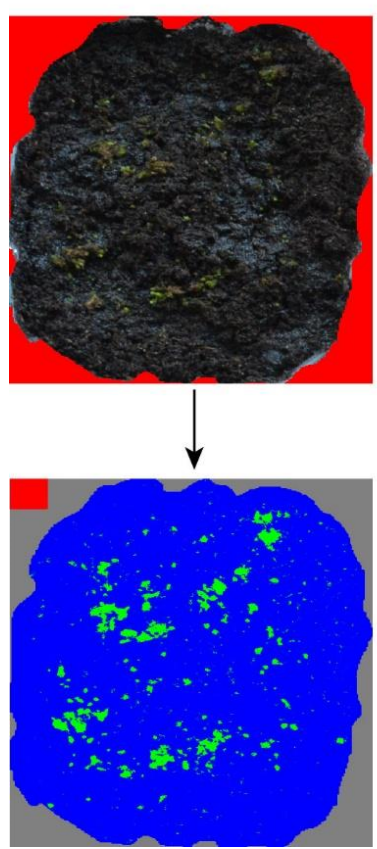

$\mathbf{T}_{5}$

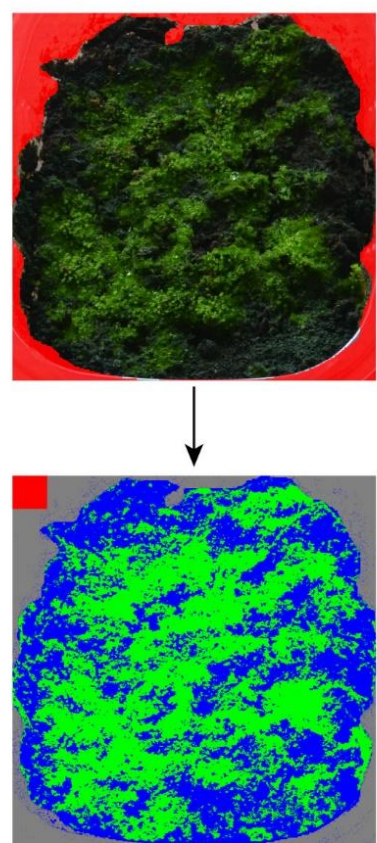

$\mathbf{T}_{8}$

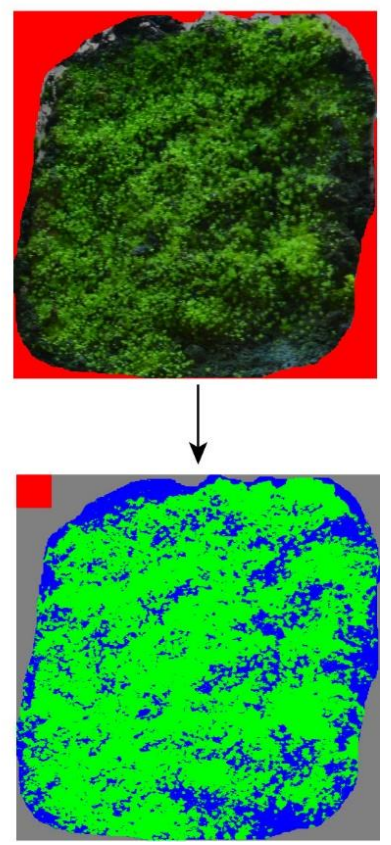

Figure 2. Images of Tortella nitida at time $0\left(T_{0}\right), 5\left(T_{5}\right)$ and $8\left(T_{8}\right)$ weeks and their corresponding pixel coverage analysis.

\subsection{Statistical Analysis}

To characterize the growth of the different moss species and their response to temperature and photoperiod, we fitted generalized additive models (GAM) to the percentage cover data for each combination of treatments using the "gam" function of the "mgcv" $\mathrm{R}$ package [42] and "ggplot2" package [43] to plot them. The statistical analysis was performed in version R 3.4.3 [44]. 


\section{Conclusions}

The findings of this study demonstrate that it is possible to grow moss artificially in plastic containers with organic gardening substrate without fertilisers, achieving an average coverage of the culture area of more than $60 \%$ in $5-8$ weeks. The growth of all species except T. nitida is linear and sustained at $15^{\circ} \mathrm{C}$. At other temperatures $\left(20^{\circ} \mathrm{C}\right.$ and $\left.25^{\circ} \mathrm{C}\right)$, regardless of the photoperiod, growth stops, and the moss dies after some weeks. This would confirm that moss culture in the laboratory could be of great help for further use in environmental projects. Finally, in a future of global change with higher temperatures and more periods of drought, $C$. introflexus could successfully occupy the niche of other native moss species, especially in degraded areas.

Author Contributions: Conceptualization, Z.V., C.B. and R.C.d.C.; methodology, Z.V., R.C.d.C. and T.A.d.P.; software, C.R.; validation, C.B. and T.A.d.P.; formal analysis, Z.V. and C.R.; investigation, Z.V. and R.C.d.C.; resources, C.B., T.A.d.P. and R.C.d.C.; data curation, Z.V., C.R. and R.C.d.C.; writingoriginal draft preparation, Z.V. and C.R.; writing-review and editing, all authors.; visualization, Z.V. and C.R.; supervision, C.B.; project administration, R.C.d.C.; funding acquisition, R.C.d.C. and C.B. All authors have read and agreed to the published version of the manuscript.

Funding: This study was supported by the project MedMossRoofs (PTDC/ATPARP/5826/2014) funded by the "Portuguese Foundation for Science and Technology", Portugal.

Institutional Review Board Statement: Not applicable.

Informed Consent Statement: Not applicable.

Data Availability Statement: Not applicable.

Acknowledgments: Z. Varela was supported by a postdoctoral research grant awarded by the Autonomous Government of Galicia (Xunta de Galicia, Spain). The support of the "Portuguese Foundation for Science and Technology", I.P., Portugal, through the grant attributed to the research unit LEAF (UID/AGR/04129/2020) is also acknowledged.

Conflicts of Interest: The authors declare no conflict of interest.

\section{References}

1. DeFalco, L.A.; Detling, J.K.; Tracy, C.R.; Warren, S.D. Physiological variation among native and exotic winter annual plants associated with microbiotic crusts in the Mojave Desert. Plant Soil 2001, 234, 1-14. [CrossRef]

2. Alpert, P.; Oliver, M.J. Drying without dying. In Desiccation and Survival in Plants; Black, M., Pritchard, H.W., Eds.; CABI Publishing: Wallingford, UK, 2002; pp. 3-43.

3. Cruz de Carvalho, R.; Catalá, M.; Branquinho, C.; Marques da Silva, J.; Barreno, E. Dehydration rate determines the degree of membrane damage and desiccation tolerance in bryophytes. Physiol. Plant. 2017, 159, 277-289. [CrossRef]

4. Cruz de Carvalho, R.; Maurício, A.; Pereira, M.F.; Marques da Silva, J.; Branquinho, C. All for One: The Role of Colony Morphology in Bryophyte Desiccation Tolerance. Front. Plant Sci. 2019, 10, 1360. [CrossRef]

5. Hilty, J.H.; Eldridge, D.J.; Rosentreter, R.; Wicklow-Howard, M.C.; Pellant, M. Recovery of biological soil crusts following wildfire in Idaho. J. Range Manag. 2004, 57, 89-96. [CrossRef]

6. Memon, M.K.C.; Lal, M. Problems of development in mosses and moss allies. Proc. Natl. Acad. Sci. USA 1981, B47, 115-152.

7. Varela, Z.; Roiloa, S.R.; Fernández, J.A.; Retuerto, R.; Carballeira, A.; Aboal, J.R. Physiological and growth responses of transplants of the moss Pseudoscleropodium purum to atmospheric pollutants. Water Air Soil Pollut. 2013, 224, 1753. [CrossRef]

8. Ares, A.; Varela, Z.; Aboal, J.R.; Carballeira, A.; Fernández, J.A. Active biomonitoring with the moss Pseudoscleropodium purum: Comparison between different types of transplants and bulk deposition. Ecotoxicol. Environ. Saf. 2015, 120, 74-79. [CrossRef]

9. Bowker, M.A.; Belnap, J. A simple classification of soil types as habitats of biological soil crusts on the Colorado Plateau, USA. J. Veg. Sci. 2008, 19, 831-840. [CrossRef]

10. Cruz de Carvalho, R.; dos Santos, P.; Branquinho, C. Production of moss-dominated biocrusts to enhance the stability and function of the margins of artificial water bodies. Restor. Ecol. 2018, 26, 419-421. [CrossRef]

11. Garabito, D.; Vallejo, R.; Montero, E.; Garabito, J.; Martínez-Abaigar, J. Green buildings envelopes with bryophytes. A review of the state of the art. Boletín Soc. Española Briología 2017, 48-49. Available online: https:/ / docplayer.es/111392867-Boletin-de-lasociedad-espanola-de-briologia-2017-contenidos.html (accessed on 29 August 2021).

12. Tian, G.Q.; Bai, X.L.; Xu, J.; Wang, X.D. Experimental Studies on the Natural Restoration and the Artificial Culture of the Moss Crusts on Fixed Dunes in the Tengger Desert, China. Front. Biol. China 2006, 1, 13. [CrossRef]

13. Bai, X.L.; Wang, Y.; Xu, J.; Li, X.R.; Zhang, J.G. Characteristics of reproduction and growth of mosses in the soil crust of fixed dunes in Shapotou area. Chin. J. Desert Res. 2003, 23, 172-176. 
14. Xu, S.; Yin, C.; He, M.; Wang, Y. A technology for rapid reconstruction of moss-dominated soil crusts. Environ. Eng. Sci. 2008, 25, 1129-1138. [CrossRef]

15. Chen, Y.Q.; Zhao, Y.G.; Ran, M.Y. Experimental research on artificial culture method of moss crust in Hilly Loess Plateau region. Acta Bot. Boreali-Occident. Sin. 2009, 29, 586-592.

16. Xiao, B.; Wang, Q.H.; Zhao, Y.G.; Shao, M.A. Artificial culture of biological soil crusts and its effects on overland flow and infiltration under simulated rainfall. Appl. Soil Ecol. 2011, 48, 11-17. [CrossRef]

17. Xiao, B.; Zhao, Y.; Wang, Q.; Li, C. Development of artificial moss-dominated biological soil crusts and their effects on runoff and soil water content in a semi-arid environment. J. Arid. Environ. 2015, 117, 75-83. [CrossRef]

18. Bu, C.F.; Yang, J.Z.; Zhang, X.C. Cultivation experiment of moss plants from biological soil crusts in Mu Us sandy land. Chin. J. Desert Res. 2011, 31, 937-941.

19. Doherty, K.D.; Antoninka, A.J.; Bowker, M.A.; Ayuso, S.V.; Johnson, N.C. A novel approach to cultivate biocrusts for restoration and experimentation. Ecol. Restor. 2015, 33, 13-16. [CrossRef]

20. Antoninka, A.; Bowker, M.A.; Reed, S.C.; Doherty, K. Production of greenhouse-grown biocrust mosses and associated cyanobacteria to rehabilitate dryland soil function. Restor. Ecol. 2015, 24, 324-335. [CrossRef]

21. Zhao, Y.; Bowker, M.A.; Zhang, Y.; Zaady, E. Enhanced recovery of biological soil crusts after disturbance. In Biological Soil Crusts: An Organizing Principle in Drylands; Springer International Publishing: Berlin/Heidelberg, Germany, 2016; pp. 499-523.

22. Martin, A. The Magical World of Moss Gardening; Timber Press: Portland, OR, USA, 2015.

23. Schenk, G. Moss Gardening: Including Lichens, Liverworts, and Other Miniatures; Timber Press: Portland, OR, USA, 1997.

24. Proctor, M.C.F. Physiological ecology. Bryophyt. Biol. 2000, 2, 237-268.

25. Proctor, M.C.F. The physiological basis of bryophyte production. Bot. J. Linn. Soc. 1990, 104, 61-77. [CrossRef]

26. Zotz, G.; Rottenberger, S. Seasonal changes in diel $\mathrm{CO}_{2}$ exchange of three Central European moss species: A one-year field study. Plant Biol. 2001, 3, 661-669. [CrossRef]

27. Furness, S.B.; Grime, J.P. Growth rate and temperature responses in bryophytes: II. A comparative study of species of contrasted ecology. J. Ecol. 1982, 70, 525-536. [CrossRef]

28. Glime, J.M. Ecophysiology of Development: Protonemata. In Bryophyte Ecology. Physiological Ecology; Michigan Technological University; International Association of Bryologists, 2017; Volume 1, Chapter 5-3. Available online: http:/ / digitalcommons.mtu. edu/bryophyte-ecology/ (accessed on 16 April 2021).

29. Ros, R.M.; Mazimpaka, V.; Abou-Salama, U.; Aleffi, M.; Blockeel, T.L.; Brugués, M.; Cros, R.M.; Dia, M.G.; Dirkse, G.M.; Draper, I.; et al. Mosses of the Mediterranean, an Annotated Checklist. Cryptogam. Bryol. 2013, 34, 99-283. [CrossRef]

30. Delivering Alien Invasive Species Inventories for Europe. Available online: http://www.europealiens.org/ (accessed on 20 August 2021).

31. Sérgio, C.; Garcia, C.A.; Stow, S.; Martins, A.; Vieira, C.; Hespanhol, H.; Sim-Sim, M. How are anthropogenic pressures facilitating the invasion of Campylopus introflexus (dicranaceae, Bryopsida) in mainland Portugal? Cryptogam. Bryol. 2018, 39, $283-292$. [CrossRef]

32. He, X.; He, K.S.; Hyvönen, J. Will bryophytes survive in a warming world? Perspect. Plant. Ecol. Evol. Syst. 2016, 19, 49-60. [CrossRef]

33. Proctor, M.C.F.; Oliver, M.J.; Wood, A.J.; Alpert, P.; Stark, L.R.; Cleavitt, N.L.; Mishler, B.D. Desiccation tolerance in bryophytes: A review. Bryologist 2007, 110, 595-621. [CrossRef]

34. Frahm, J.P. A Preliminary Study of The Infraspecific Taxa of Hypnum Cupressiforme in Europe; Univ.-Bibliothek, 2009; ISSN 0945-3466. Available online: http:/ / www.frahmia.de/downloads/archive_of_bryology/Archive\%2040.pdf (accessed on 28 September 2021).

35. Bjerke, J.W.; Bokhorst, S.; Zielke, M.; Callaghan, T.V.; Bowles, F.W.; Phoenix, G.K. Contrasting sensitivity to extreme winter warming events of dominant sub-Arctic heathland bryophyte and lichen species. J. Ecol. 2011, 99, 1481-1488. [CrossRef]

36. Hugonnot, V. Comparative investigations of niche, growth rates and reproduction between the native moss Campylopus pilifer and the invasive C. introflexus. J. Bryol. 2017, 39, 79-84. [CrossRef]

37. Munzi, S.; Varela, Z.; Paoli, L. Is the length of the drying period critical for photosynthesis reactivation in lichen and moss components of biological soil crusts? J. Arid Environ. 2019, 166, 86-90. [CrossRef]

38. Essl, F.; Steinbauer, K.; Dullinger, S.; Mang, T.; Moser, D. Little, but increasing evidence of impacts by alien bryophytes. Biol. Invasions 2014, 16, 1175-1184. [CrossRef]

39. Real, C. The Pixelclasser Package. R Package Version 1.0. 2020. Available online: https://cran.r-project.org/web/packages/ pixelclasser/index.html (accessed on 22 October 2021).

40. Bennet, K.P.; Campbell, C. Support vector machines: Hype or Hallelujah. ACM SIGKDD Explor. Newsl. 2000, 2, 1-13. [CrossRef]

41. Cortes, C.; Vapnik, V. Support-vector networks. Mach. Learn. 1995, 20, 273-297. [CrossRef]

42. Wickham, H. ggplot2: Elegant Graphics for Data Analysis; Springer: New York, NY, USA, 2016. Available online: https://ggplot2 .tidyverse.org (accessed on 20 July 2021).

43. Wood, S.N. Generalized Additive Models: An Introduction with R, 2nd ed.; Chapman and Hall/CRC: London, UK, 2017.

44. R Core Team. R: A Language and Environment for Statistical Computing; R Foundation for Statistical Computing: Vienna, Austria, 2014. 